\title{
Influence of Corporate Social Responsibility on Financial Performance: A Case Study of over One Hundred Large Enterprises in China
}

\author{
Hsu Wen-Chung, Cheng Yi-Ting, Ho Wen-Cheng* \\ Department of International Business Studies, National Chi Nan University, Taiwan
}

Copyright $(2019$ by authors, all rights reserved. Authors agree that this article remains permanently open access under the terms of the Creative Commons Attribution License 4.0 International License

\begin{abstract}
This research explores the relations between the two financial performance indexes of return on assets (ROA) and return on sales (ROS) using the index of corporate social responsibility (CSR), and categorizes. It also screens out 150 sample enterprises according to their different ownerships based on the CSR initiative formulated by CSR Research Center, Division of Economics, Chinese Academy of Social Sciences and the materials about performance of enterprises in implementing CSR during 2009-2014. The empirical results of this research show that: (1) a sound responsibility management system can help put in place the communication channels with stakeholders, properly handle disputes in managing CSR issues, and maintain long-term partnership; (2) by implementing market responsibility, enterprises can promote industrial development, advocate the idea of fair competition and system guarantee, and help the whole value chain to yield prominent and continuous benefits; (3) some private enterprises are not aware of the transition of management modes, for they hold that shouldering social responsibility is to cause increased expenditure and ultimately short-term cost expenditure, hence leading to lowering operating income; and (4) the expenditure incurred to enterprises in undertaking environment responsibility behaviors can hardly be responded to in a short term, so it is likely to cause declining financial performance.
\end{abstract}

Keywords CSR, Return on Assets, Return on Sales

\section{Introduction}

\subsection{Research Background and Motivation}

There were few studies involving in CSR performance.
Whether in European and American areas or Asian countries, most research simply adopted certain single index in CSR to discuss corporate performance, such as stakeholders (Cornell and Shapiro, 1987), technological research and development (Coombs and Bierly,2006), eco-environment (Kun-Hong Lin, 2004), etc., instead of conducting research by the CSR index as a whole. Most research related to CSR focused on the performance or management system of singular industry in the area of CSR, such as construction industry and financial industry (Huang Zhongfa, Zheng Lihua, 2012).

Therefore, this research firstly categorizes listed companies according to their ownership, and then discusses whether the CSR executed by the enterprises with different types of ownership will influence financial performance.

\subsection{Research Objectives}

This research takes the emerging market as research object, discusses how different the influence of CSR indexes (responsibility management, market responsibility, social responsibility and environment responsibility) upon financial performance is the CSR initiative formulated by CSR Research Center, Division of Economics, Chinese Academy of Social Sciences and the materials about performance of enterprises in implementing CSR during 2009-2014. Besides, the factor of enterprise ownership is included into the research for more detailed analysis, thereby probing into the differences in CSR performance and financial performance between overall corporate environment, state-owned enterprises, private enterprises and foreign-owned enterprises. The research objectives are as follows:

(1) Discuss the relations between CSR performance and financial performance, and how they influence each other. 
(2) Explore the relations between CSR performance and financial performance, and compare their differences under different ownership.

\section{Literature Review}

\subsection{Corporate Social Responsibility}

\subsubsection{CSR Index and Definition}

\section{CSR Index System}

This research adopts the theoretical model built by the CSR Research Center, Division of Economics, Chinese Academy of Social Sciences in 2013, namely the "quaternity" theory covering responsibility management, market responsibility, social responsibility and environment responsibility. In this paper, the unique data set of CSR scores obtained from the CASS-CSR were utilized. The CASS-CSR was founded in February 2008 as a part of Chinese Academy of Social Sciences' Department of Economics and is China's only national research center in the CSR field. Since 2009, the CASS-CSR has collected data and scored firms according to the four dimensions of responsibility management, market responsibility, social responsibility, and environmental responsibility. The research analysts at the CASS-CSR give 100 evaluation points per dimension per firm, where all data used for evaluation must be objective and publicly available, such as CSR and annual reports, official filings, and firms' websites.

\subsubsection{CSR Definition}

CSR is also referred to as the ideas like corporate citizenship, corporate social performance and corporate sustainable development. With the awakening citizenship awareness among social public, the increasing concern about the issues like destruction and reduction of environmental resources by social public and the exploited labor organization, as well as the rising distrust in the product and service of profit-making enterprises, more attention has been drawn to whether the information of social responsibility activities carried out by enterprises is transparent, and whether enterprises have earnestly engaged in social issues like public welfare, environmental protection or education while pursing the goal of profit maximization (CSR Research Center, Division of Economics, Chinese Academy of Social Sciences, 2014).

According to CSR Research Center, Division of Economics, Chinese Academy of Social Sciences, CSR is defined as: the responsibilities to the society that enterprises have to bear in carrying out operation activities, in which the society refers to the overall environment consisted of all stakeholders, including shareholders, employees, clients, government, suppliers, and community.

\subsection{Relations between Responsibility Management and Financial Performance}

Responsibility management integrates the whole enterprise with stakeholders through the six parts of strategy, governance, integration, performance, communication and ability, so as to enable the implementation of sustainable operation philosophy.

Starting from the viewpoints of stakeholders theory, this research finds out that stakeholders related to enterprises would firstly observe the effect of their performance in CSR and then determine whether to bring closer the cooperation between two companies (Hillman and Keim, 2001). Therefore, if an enterprise is good at fulfilling social responsibility and maintaining sound relationship with stakeholders, the operation risks would be lowered and the operation performance uplifted (Freeman, 1984).

Seen from the angle of communication, when an enterprise meets the demand of stakeholders, its time cost consumed in concluding standard contract or oral agreement will be cut down (Williamson, 1975). Therefore, establishing a sound corporate image can more quickly and easily maintain sound cooperation with stakeholders, hence lowering transaction cost and increasing substantial benefit for enterprises themselves.

In the end, seen from the angle of promoting corporate social responsibility governance, some scholars held that a sound social responsibility management system and organization system established by enterprises would effectively put in place favorable interaction with stakeholders, produce satisfactory social performance, properly handle disputes in social responsibility issues between enterprises and stakeholders, maintain long-term cooperative partnership, and create competitive edges, thereby soliciting more external investors, creating profits for shareholders and uplifting financial performance (Barnett and Salomon, 2006).

H1: The enterprises with better responsibility management performance will see better financial performance.

\subsection{Relations between Market Responsibility and Financial Performance}

Market responsibility refers to the responsible behaviors for shareholders, clients and cooperation partners (internal and external stakeholders) in market economy, so this research strives to locate relevant literature from these three directions that proves market responsibility can uplift financial performance.

Seen from client responsibility, the influence of R\&D upon company market value will be reflected on the share price. Whenever an enterprise announces to initiate $R \& D$ investment or plan, the share price would show forward reaction (Jarrell et al., 1985; Kothari and Zimmerman, 1995), while the enterprises possessing relatively high $R \& D$ capacity would mostly witness high performance and 
market value (Garner et al., 2002). In addition, Morbey (1990) also demonstrated that regardless of company scale, technological R\&D effort is significantly positively correlated to profit growth in the following 10 years, and so does it even in different industries. Empirical results also showed that $R \& D$ investment and operation performance both have a positive and significant influence, no matter measured from the number of patent approvals or the number of applications; and this is the reason why enterprises have to keep innovative R\&D investment to maintain corporate competitiveness and boost financial performance (Liu Zhengtian, Lin Xiuwei et al., 2005).

Seen from the value chain responsibility in partner responsibility, $\mathrm{Li}$ et al. proposed the strategic supplier partnership in 2006, a long-term cooperative relationship developed with suppliers. Through making full use of the strategy and operation ability that suppliers have developed in participating in the organization, it takes technical measures, structural measures, and logistical measures as the research variables for measuring supply chain management practice, discussing the influence of supply chain management practice, integration and competitiveness on performance, with a view to helping the value chain to realize prominent sustainable benefit (Kim, 2011).

H2: The enterprises with better market responsibility performance will see better financial performance.

\subsection{Relations between Social Responsibility and Financial Performance}

Social responsibility refers to the behaviors of enterprises to undertake their responsibilities for and contribute to the government, employees, production environment, and the community in operation activities. Therefore, based on the cases of relevant legal system, employee protection measures and community participation, this research aims at summarizing and collating whether the financial performance of the enterprises that have earnestly fulfilled social responsibility is improved accordingly.

Seen from the welfare system in employee responsibility, as for the allocation of company dividend and bonus, the dividend allocation percentage shall be stipulated in the articles of association apart from the percentage for shareholders; and in surplus allocation, it shall be allocated to employees according to certain percentage as well. Research showed that profit sharing and stock ownership are more stimulating than other employee stock ownership initiatives, and have a positive influence upon financial performance (Chen Longqi, Weng Ni, 1992). Skinner (1996) and Gillan (2001) pointed out that there is stimulating effect in stock option, and the stock option released can enhance employees' motivation and realize the goal of shareholders value maximization, not to mention the benefits of lowering separation rate and improving work performance. This effect means that the value of stock option is positively correlated with share price.

Relevant research on safe production suggested that the provision of a favorable and safe work environment would help uplift the productivity (Turban and Greening, 1997), lower the occurrence rate of negative special events and uplift the bearing capacity against the events (Tsoutsoura, 2004), just like buying insurance for the company brand image and financial performance (Werther and Chandler, 2005; Peloza, 2006).

It could be known from relevant literature of community participation that engagement in charity or donation can uplift corporate reputation and public trust (Bowman, 1975; Alexander, 1978), and enhance corporate image and competitiveness, thus lowering the expenditure on advertisement (Portner, 1995; Fombrun et al., 2000).Meanwhile, it promises to win the favor of investment organizations (Spicer, 1978; Moussavi, 1986) and significantly cut down the expenditures on operation cost. Several scholars have investigated the relationship between firms' CSR and risk, and their results show that CSR helps improve a firm's performance and reduce its business risks (Lee \& Faff, 2009). Some research has even found that CSR engagement can significantly reduce financial risk and improve a firm's credit rating (Bassen, Meyer, \& Schlange, 2006; Hsu \& Chen, 2015; Verwijmeren \& Derwall, 2010).

H3: The enterprises with better social responsibility performance will see better financial performance.

\subsection{Relations between Environment Responsibility and Financial Performance}

Environment responsibility refers to the due obligation and responsibility in energy saving, emission reduction and environmental protection that enterprises should bear in conducting corporate operation activities. Emission load and pollutants have to be reduced through implementing relevant policies and measures for energy saving and emission reduction; water and soil conservation and landscaping in construction environment should be done well to bring a clean and comfortable environment to the public. This research will discuss whether the financial performance can be improved after implementing these policies and measures.

Environmental information related to corporate operation business is made public to the society through media, official website or report, so as to make transparent the normally secret information and allow stakeholders to clearly see that the enterprise is responsible for the environment and therefore is reliable. Through communication, information previously revealed can be obtained.

When enterprises and stakeholders establish sound 
information disclosure channels, the corporate resources utilization rate and effect would be uplifted (Orlitzky, 2003), and ultimately it would be reflected in the improvement of financial performance (Waddock, 1997).

Disclosure of more environment related promises and practical information by enterprises, apart from accumulating the organizational reputation resources and establishing legitimate status (Gray, 1995; Cho, 2009; Deegan, 2000; Hooghiemstra, 2000), can also uplift the product innovation ability and dynamic environmental protection demand response ability (Chatman, 1994; Shrivastava, 1995), and enhance brand image and corporate reputation (Brown, 1997; Maignan, 2001), which, ultimately, will be reflected inthe satisfactory financial performance.

Seen from the literature in green supply chain, environmental protection activities can bring certain benefits to corporate financial performance through, for example, environment management system, so that materials procurement cost, energy consumption, waste discharge and handling fee as well as penalty for accidents can be lowered (Zhu and Sarkis, 2004). Moreover, some wastes could be recycled for reuse, hence saving internal operation cost expenditures.

H4: The enterprises with better environment responsibility performance will see better financial performance.

\subsection{Measurement Variables of Financial Performance}

Compared with others, the three indexes of ROA, ROS and ROE are more often taken as the indexes for measuring corporate performance. However, ROE is sensitive to capital structure changes (Hitt et al., 1997), so it is not very applicable. ROA and ROS were adopted in previous research. Therefore, this research uses ROA and ROS as the measurement variables for corporate financial performance.

\subsection{Control Variables}

Kotabe et al. (2002) took assets and number of employees as company scale, finding out that the companies with a larger scale and more employees can enjoy more resources and information, more rapidly conduct investment layout in the Mainland, and more easily reach scale economy to ultimately improve the financial performance. The public may take the initiative to note and examine whether a company can deliver the social responsibility performance expected by the society (Forbrun, 1990), so the company scale and the degree of fulfilling social responsibility is related -- the enterprises with a larger scale are more required to fulfill corporate social responsibility.

Since establishment, enterprises should always hold on to the philosophy of sustainable development (Chen Xupan,
2007), constantly making investment, innovating R\&D, expanding market and improving operation ability to enhance competitive edges. For common companies, if they want to move onto the international stage, they must operate and learn for a long time, and only after accumulating enough experience in the market, can they move forward into overseas investment and set up branches.

This research is expected to unveil whether enterprise scale and experience accumulated since establishment can influence the relations between corporate social responsibility and financial performance with the help of control variables. Therefore, this research adopts the number of years of establishment and company scale (number of employees and assets) as the control variables.

\section{Research Methodology}

\subsection{Research Framework}

On the basis of reviewing previous literature, this research focuses on discussing what's the relationship between CSR and financial performance, and categorizing CSR into four types, namely responsibility management, market responsibility, social responsibility, and environment responsibility. Finally, with the help of the number of employees and the number of the years of establishment as control variables, it also strives to explore whether CSR performance of enterprises can really influence financial performance as indicated in this research.

\subsection{Research Hypotheses}

This research has four hypotheses, namely H1, H2, H3 and $\mathrm{H} 4$, as shown in the following Table 1.

Table 1. Table of Research Hypotheses

\begin{tabular}{|l|l|}
\hline No. & \multicolumn{1}{|c|}{ Content } \\
\hline H1 & $\begin{array}{l}\text { The enterprises with better responsibility management } \\
\text { performance will see better financial performance }\end{array}$ \\
\hline H2 & $\begin{array}{l}\text { The enterprises with better market responsibility performance } \\
\text { will see better financial performance }\end{array}$ \\
\hline H3 & $\begin{array}{l}\text { The enterprises with better social responsibility performance } \\
\text { will see better financial performance }\end{array}$ \\
\hline H4 & $\begin{array}{l}\text { The enterprises with better environment responsibility } \\
\text { performance will see better financial performance }\end{array}$ \\
\hline
\end{tabular}

\subsection{Research Design}

\subsubsection{Data Source}

There are two sources to the CSR related information and financial data of over one hundred large enterprises in China, namely Taiwan Economic Journal (TEJ) and CSR Research Center, Division of Economics, Chinese Academy of Social Sciences. 


\subsubsection{Research Object}

Taking the over one hundred large enterprises in China as research object and based on the Top 500 Chinese enterprises released by China Enterprise Confederation and Fortune Magazine, this research conducts screening as per capital holding and operating income. To ensure the integrity of variables, missing values and unreasonable observed values are eliminated. Finally, there are 150 enterprises selected, namely 61 state-owned enterprises, 54 private enterprises, and 35 foreign-owned enterprises.

\subsubsection{Research Methodology}

CSR development index is a composite index for evaluating the CSR management system construction status and social and environmental information exposure level. The research approaches are as follows:

1. Continue with the quaternity theoretical model of responsibility management, market responsibility, social responsibility and environment responsibility.

2. Refer to international social responsibility index like ISO26000, domestic social responsibility initiative and world top 500 enterprises social responsibility indexes.

3. Refer to the social responsibility reports involved in world top 500 enterprises, to draw upon the industrial key indexes and divide industrial social responsibility index system.

4. Collect all social responsibility related information of top 100 state-owned enterprises, top 100 private enterprises and top 100 foreign-owned enterprises during 2009-2014 from CSR reports, corporate annual reports, reports on singular issue, and official websites.
5. Analyze and conduct quantitative evaluation of CSR information, calculate the initial score for CSR development index, adjust the initial score according to responsibility awards, responsibility absence and innovative management, so as to obtain the final score and ranking of CSR development index.

\subsubsection{Data Analysis Method}

This research adopts the panel data containing cross-section data and time-series data, and uses Eviews7 statistical software as the research tool for regression analysis. The goal of regression analysis lies in studying the relations between independent variables and dependent variables, locating the relevant direction and intensity, discussing the influence of control variables, building the model used to observe or predict over the variables that researchers might be interested in. This research will use panel data regression for analysis.

\section{Empirical Results and Analysis}

\subsection{Narrative Statistical Analysis}

This section conducts narrative statistical analysis of the research samples, as shown in the following Table 2. In the research samples, the average age of manufacturers is 27.55 years, the average number of employees is 75879 , the average responsibility management index is $33.048 \%$, the average social responsibility index is $36.138 \%$, the average market responsibility index is $41.169 \%$, the average environment responsibility index is $32.189 \%$, and the average total assets are 6.44 million RMB.

Table 2. Narrative statistics analysis of the research samples

\begin{tabular}{|c|c|c|c|c|}
\hline Item/units & Mean & Minimum & Maximum & Std.Dev. \\
\hline Number of the years of Establishment & 27.55 & 5 & 107 & 21.438 \\
\hline Number of Employees & 75879 & 194 & 530772 & 115201.9 \\
\hline Responsibility Management index & 33.048 & 0 & 100 & 27.219 \\
\hline Market Responsibility index & 41.169 & 0 & 93.75 & 23.273 \\
\hline Social Responsibility index & 36.138 & 0 & 96.3 & 24.815 \\
\hline Environment Responsibility index & 32.189 & 0 & 100 & 25.09 \\
\hline Return on assets (\%) & 2.76 & -2.085 & 285.9 & 8.39 \\
\hline Return on sales (\%) & 4.54 & 3 & 118.29 & 1.21 \\
\hline Total assets (Million RMB) & 6.44 & 0.11176 & 20.02 & 2.29 \\
\hline
\end{tabular}




\subsection{Regression Analysis}

Regression analysis is adopted to verify the influence of CSR system index, number of the years of establishment, assets, and number of employees upon financial performance. The following Table 3 and 4 will show the research results of 150 enterprises and manufacturers. The enterprises are divided into overall enterprises, state-owned enterprises, private enterprises, and foreign-owned enterprises, thereby discussing the respective relations of CSR and control variables to financial performance, and the influence therein.

Table 3. Regression Analysis Results of CSR and ROA

\begin{tabular}{|c|c|c|c|c|}
\hline Variable & Overall & State-owned & Private & Foreign-owned \\
\hline \multirow{2}{*}{ Constant } & $-352.363 * * *$ & $109.001 * *$ & $-269.397 * *$ & $136.272 * * *$ \\
\hline & $(1.805)$ & $(0.313)$ & $(-0.354)$ & $(1.036)$ \\
\hline \multirow{2}{*}{ 1.Number of the years of Establishment } & $12.812 * * *$ & $7.161 *$ & $3.110^{*}$ & $0.868 * * *$ \\
\hline & $(4.412)$ & $(1.409)$ & $(-1.71)$ & $(23.624)$ \\
\hline \multirow{2}{*}{ 2.Total Assets } & $6.770 *$ & $-0.124 * * *$ & $0.793 * * *$ & $0.152 * * *$ \\
\hline & $(2.565)$ & $(29.915)$ & $(11.319)$ & $(3.968)$ \\
\hline \multirow{2}{*}{ 3.Number of Employees } & 2.508 & 74.132 & $37.306 * * *$ & -6.462 \\
\hline & $(1.128)$ & $(0.749)$ & $(4.304)$ & $(-1.893)$ \\
\hline \multirow{2}{*}{ 4.Responsibility Management } & $0.320 * * *$ & $3.507 * * *$ & $3.169 * *$ & $23.325^{* *}$ \\
\hline & $(0.064)$ & $(-3.678)$ & $(0.104)$ & $(0.735)$ \\
\hline \multirow{2}{*}{ 5.Market Responsibility } & $6.123 * * *$ & 1.256204 & $4.732607 *$ & $25.897 * *$ \\
\hline & $(1.223)$ & $(1.294)$ & $(1.553)$ & $(0.765)$ \\
\hline \multirow{2}{*}{ 6.Social Responsibility } & $10.194 *$ & $6.580474 * * *$ & -5.890918 & $3.357^{*}$ \\
\hline & $(1.628)$ & $(5.118)$ & $(-1.668)$ & $(0.906)$ \\
\hline \multirow{2}{*}{ 7.Environment Responsibility } & -0.533 & $-3.060 * * *$ & $-1.578^{*}$ & $-3.704 *$ \\
\hline & $(-0.116)$ & $(-2.995)$ & $(-0.589)$ & $(-1.468)$ \\
\hline Sample & 150 & 61 & 54 & 35 \\
\hline R-squared & 0.613 & 0.913 & 0.674 & 0.936 \\
\hline Adjusted R-squared & 0.529 & 0.907 & 0.657 & 0.930 \\
\hline Durbin-Watson stat & 1.001 & 1.467 & 1.243 & 1.216 \\
\hline
\end{tabular}

t-Statistic $*: p<0.1,{ }^{* *}: \mathrm{p}<0.05,{ }^{* * *}: \mathrm{p}<0.01$

Table 4. Regression Analysis Results of CSR and ROS

\begin{tabular}{|c|c|c|c|c|}
\hline Variable & Overall & State-owned & Private & Foreign-owned \\
\hline \multirow{2}{*}{ Constant } & $471.660 * * *$ & $-235.672 * *$ & $-156.560 * *$ & $395.667 * *$ \\
\hline & $(9.422)$ & $(-0.437)$ & $(-0.204)$ & $(1.08)$ \\
\hline \multirow{2}{*}{ 1.Number of the years of Establishment } & $1.553^{*}$ & $0.315^{*}$ & -3.201 & $6.121 *$ \\
\hline & $(2.084)$ & $(49.116)$ & $(-1.746)$ & $(0.648)$ \\
\hline \multirow{2}{*}{ 2.Total Assets } & -0.793 & $4.733 * * *$ & $1.223 * * *$ & $0.881 * * *$ \\
\hline & $(-1.172)$ & $(0.601)$ & $(17.319)$ & $(9.86)$ \\
\hline \multirow{2}{*}{ 3.Number of Employees } & $0.416^{*}$ & 19.639 & $3.572 * * *$ & -8.662 \\
\hline & $(0.73)$ & $(1.281)$ & $(4.089)$ & $(-2.126)$ \\
\hline \multirow{2}{*}{ 4.Responsibility Management } & $0.564 *$ & $4.136^{* *}$ & $6.026^{*}$ & $2.936^{* *}$ \\
\hline & $(0.44)$ & $(2.799)$ & $(0.196)$ & $(0.379)$ \\
\hline \multirow{2}{*}{ 5.Market Responsibility } & $0.213^{* *}$ & -5.123 & $4.530^{*}$ & $8.204 *$ \\
\hline & $(0.16)$ & $(0.34)$ & $(1.475)$ & $(0.942)$ \\
\hline \multirow{2}{*}{ 6.Social Responsibility } & $-1.391^{*}$ & $7.755 * * *$ & $-6.615 *$ & $2.012 *$ \\
\hline & $(-0.867)$ & $(3.891)$ & $(-1.858)$ & $(2.372)$ \\
\hline \multirow{2}{*}{ 7.Environment Responsibility } & $2.917^{*}$ & $-2.793 *$ & $-1.606 * *$ & $-8.987 * *$ \\
\hline & $(2.478)$ & $(-1.763)$ & $(-0.594)$ & $(0.134)$ \\
\hline Sample & 150 & 61 & 54 & 35 \\
\hline R-squared & 0.583 & 0.866 & 0.804 & 0.586 \\
\hline Adjusted R-squared & 0.516 & 0.864 & 0.794 & 0.548 \\
\hline Durbin-Watson stat & 1.532 & 1.374 & 1.554 & 1.273 \\
\hline
\end{tabular}

t-Statistic ${ }^{*}: \mathrm{p}<0.1,{ }^{* *}: \mathrm{p}<0.05,{ }^{* * *}: \mathrm{p}<0.01$ 
According to Table 4, the responsibility management, market responsibility, social responsibility, number of the years of establishment and total assets in overall enterprises reach the level of significance, among which the responsibility management and market responsibility can most influence ROA for they reach the highest. According to Table 3, all the CSR variables, number of the years of establishment and number of employees in overall enterprises reach the level of significance, among which the index of social responsibility is negatively correlated; the index of market responsibility reaches the highest level of significance, so it can most influence ROS.

According to Table 4, the responsibility management, social responsibility, environment responsibility, number of the years of establishment and total assets in state-owned enterprises reach the level of significance, among which environment responsibility and total assets are negatively correlated, and responsibility management, market responsibility, environment responsibility and total assets are likely to influence ROA. According to Table 3, the responsibility management, social responsibility, environment responsibility, number of the years of establishment and total assets in state-owned enterprises reach the level of significance, among which the index of environment responsibility is negatively correlated, and social responsibility is most likely to influence ROS.

According to Table 4, the responsibility management, market responsibility, environment responsibility and control variables in private enterprises reach the level of significance, among which environment responsibility is negatively correlated, and responsibility management can most influence ROA. According to Table 3, all the CSR variables, total assets and number of employees in private enterprises reach the level of significance, among which social responsibility and environment responsibility are negatively correlated, and the results show that the latter can most influence ROS.

According to Tale 4-2, all the CSR variables, number of the years of establishment and total assets in foreign-owned enterprises reach the level of significance, among which environment responsibility is negatively correlated, and the results show that responsibility management and market responsibility can most influence ROA. According to Table 3, all the CSR variables, number of the years of establishment and total assets in foreign-owned enterprises reach the level of significance, among which environment responsibility is negatively correlated, and responsibility management and environment responsibility can most influence ROS.

\section{Conclusions and Suggestions}

\subsection{Research Conclusions}

To implement CSR and reach the goal of performance growth, enterprises have to establish responsibility management system. Only in this way, can they effectively carry out favorable interaction with stakeholders, properly handle the disputes in CSR, maintain long-term partnership, and create corporate competitive edges, thus soliciting more investors, creating shareholders profit and uplifting financial performance.

Combining with supplier partners, developing long-term cooperation, carrying out integration of technology, resources and channel platforms can help the whole value chain to secure prominent and sustainable benefits.

Ensuring the rights and interests, career development and safe work environment of employees can enhance the motivation of employees, lower the separation rate and occurrence rate of negative events, and uplift work performance and productivity.

If there are negative relations between corporate environment responsibility and financial performance, the enterprises will bear penalty for damaging the environment. When an enterprise itself falls into an industry with high environment sensitivity, negative impression will be arising in the society once there is any negative environment information outflowing, leading to financial impact. Most enterprises are unwilling to undertake environment responsibility or just undertake it with a perfunctory attitude, because environmental governance requires input of a large amount of capital that cannot be recovered in a short term, and no positive response will be fed back for the unsound impression on society.

\subsection{Research Limitations}

\subsubsection{Insufficient Data}

This research adopts Chinese enterprises as the research object. And the data source for financial performance mainly comes from TEJ. Given that the archived information of Chinese enterprises is less when compared with the enterprises in other regions, the research database built in this research is defected by partial missing values, which will be calculated as N/A when using Eviews statistical software for estimation.

\subsubsection{CSR Scoring System}

Given that the rating information collected comes from website, newspapers, magazines and CSR reports, this kind of selection tasks featured by subjective consciousness will witness certain deviations due to individual self-thoughts and habits. Although means like auditing and cross comparison can lower the collection error rate, inaccuracy is still likely to arise in the final totaling score.

\subsubsection{Attention of Enterprises Paid on CSR Report}

An enterprise's attention on compiling social responsibility report will directly affect its score in CSR indexes. And the attention degree can be divided into five types, namely outstanding, leading, chasing, starting and 
onlooking. Enterprises fall into different types according to their degree of attention in turn.

The enterprises falling into outstanding should have already established a sound CSR system in implementing CSR, and been able to release complete information about social responsibility to social public through different layers of channels. The enterprises falling into leading and chasing are at the stage of gradually establishing the social responsibility management system, and the information about social responsibility related issues released to the public is only basic information. The enterprises falling into starting are just making the first step in the work of social responsibility, with no time or opportunity to establish social responsibility management system and with disclosed information scattered and one-sided. The enterprises falling into onlooking have not made any efforts in the work related to CSR, with serious insufficiency in relevant information and system establishment.

Since this research adopts the CSR report rating of Academy of Social Sciences and TEJ financial data as the basis for samples, every enterprise can complete one perfect social responsibility report through the guidance of the center or by itself. However, there can be a scenario where an enterprise may be given a low rating score, even though its operation status is satisfactory, forits true purpose for conducting social responsibility behaviors is just to meet the requirements of government policies and public expectation. And the samples like this will cause error.

\subsection{Research Suggestions}

\subsubsection{Supplementation of Insufficient Data}

Due to the fact that data in sufficiency may cause errors in the estimated results, scholars should supplement or increase the research range or number of enterprise sin the future research, so as to complete the data and enhance the accuracy of regression results.

\subsubsection{Increasing Industrial Richness and Diversity}

The 150 Chinese enterprises selected in this research are well distributed in various sectors and industries, but this research only differentiates them according to the ownership type. In the future research, discussions can be conducted as per different industries, with a view to increasing the industrial richness and diversity and ultimately enabling the owners of enterprises in various industries to know how to undertake social responsibility to uplift financial performance.

\subsection{Policy Suggestion}

\subsubsection{Social Responsibility Legalization}

The government should reward the enterprises that have indeed implemented social responsibility policies by granting appropriate preference or subsidy, weld the legal means to push those enterprises with poor social responsibility awareness to take the initiative to undertake social responsibility, formulate relevant laws and regulations for social responsibility issues like employees environment, safe production, career training, environment and eco-governance, and guide enterprises to get involved in social responsibility.

\subsubsection{Enhancement of Monitoring Mechanism over Social Responsibility}

Some social institutions have to be established to ensure that enterprises fulfill social responsibility. As for the CSR rating institutions like US Innovest Group and British BITC, they can work as the window for the public by providing professional consultation services to investors, stakeholders, corporate managers and social public, including evaluation and analysis concerning corporate environment, product and production line quality, safety and environment risks, thereby enabling the enterprises to know how to undertake social responsibility or whether they have undertaken it.

\subsubsection{Improvement of Enterprises' Enthusiasm in Implementing Social Responsibility}

Enterprises have to be made aware that the cost expenditure in undertaking social responsibility and profit making are mutually promoting, and the active undertaking of social responsibility will bring various benefits to enterprises. When enterprises utilize various channels for promotion of their performance in implementing social responsibility, the positive reputation and image can be enhanced, and the social recognition boosted. If enterprises fully implement social responsibility in work environment, the loyalty and organizational recognition of employees can be won, which can not only lower demission rate, but also uplift work performance and zeal, helping to form harmonious organizational culture and attract talents.

\subsubsection{Uplifting Social Public Attention to Social Responsibility}

Under the economic system of pursuing benefit maximization, the benefit orientation harbored by the public for enterprises tends to make many enterprises to hold that social responsibility behaviors can bring about little return, so they are unwilling to undertake too much social responsibility. In view of this, the government, enterprises, all the public, all should reawaken the concept of social responsibility, enhance the publicity of the importance of social responsibility through various channels as well as the changes brought about by implementing the responsibility measures, in the hope of making the public get exposed to what actually the enterprises and the government have done to undertake CSR. 


\section{REFERENCES}

[1] Ackerman, R. W., \& Bauer, R. (Eds)., "Corporate social responsiveness: The Modern dilemma". Reston, 1976, VA: Reston

[2] Akerman, R. W. "How companies respond to social demands". Harvard Business Review, 51, pp. 88-98, 1973.

[3] Alexander, G. J. and R. A. Bucholtz, "Corporate Social Performance and Stock Market Performance," Academy of Management Journal, Vol.21, pp.479-486, 1978.

[4] Alnajjar, F. K. "Determinants of Social Responsibility Disclosures of U.S. Fortune 500 Firms: An Application of Content Analysis", Advances in Environmental Accounting and Management, Vol. 1, pp.163-200, 2000.

[5] Arrow, K. J. "Social Responsibility and Economic Efficiency" Public Policy, 21, pp.303-317, 1973.

[6] Barnett, M. L., \& Salomon, R. M. "Beyond dichotomy: the curvilinear relationship between social responsibility and financial performance". Strategic Management Journal, 27(11), pp.1101-1122, 2006.

[7] Bassen, A., Meyer, K., \& Schlange, J. "The influence of corporate responsibility on the cost of capital. An Empirical Analysis", Hamburg 2006.

[8] Becchetti, L., R. Ciciretti, and I. Hasan, "Corportate Social Responsibility and Share holder's Value: An Event Study Analysis." Working Paper, Federal Reserve Bank of Atlanta, 2007.

[9] Bowen, E. H. "Social Responsibility of the Businessman, New York: Harper and Brother", 1953.

[10] Bowman, E. H. and M. Haire, "A Strategic Posture toward Corporate Social Responsibility," California Management Review, 18, pp.49-58, 1975.

[11] Bragdon, J. and J. Marlin, "Is Pollution Profitable?" Risk Management, 19, pp.9-18, 1972.

[12] Brammer, Stephen, J., Chris. Brooks. and Stephen. Pavelin. "Corporate Social Performance and Stock Returns: UK Evidence from Disaggregate Measures", Financial Management, vol. 35, no. 3 (Autumn), 2006.

[13] Brown, T. J. \& P. A. Dacin, "The Company and the Product: Corporate Associations and Consumer Product Responses", Journal of Marketing, Vol. 61(1), pp. 68-84, 1997.

[14] Carroll, A. B. "A three-dimensional conceptual model of corporate performance". Academy of Management Review, Vol.4(4): pp.497-505,1970.

[15] Carroll, A. B. "The pyramid of corporate social responsibility: Toward the moral management of organizational stakeholder". Business Horizons, 7-8:39-48, 1991.

[16] Chatman, J. A., \& K. A. Jehn, "Assessing the Relationship between Industry Characteristics and Organizational Culture: How Different Can You Be?" Academy of Management Journal, Vol. 37(3), pp.522-553, 1994.

[17] Chung-Fah Huang. "Corporate Social Responsibility and the Relationship among Ecological Environment, Corporate Image and Organizational Performance in the Construction
Industry, Department of Civil Engineering", National Kaohsiung University of Applied Sciences, Journal of Technology, Vol 27, 2012.

[18] Coombs, J. E., and P. E. Bierly. "Measuring technological capability and performance", $R \& D$ Management, 36: pp.421-438, 2006.

[19] Cornell, B. \& Shapiro, A.C. "Corporate stakeholder and corporate finance". Financia Management, 16(1): pp.5-14, 1987.

[20] Deegan, C., Rankin, M., \& P. Voght, "Firms' Disclosure Reactions to Major Social Incidents: Australian Evidence", Accounting Forum, Vol. 24(1), pp.101-130, 2000.

[21] Ferrell, O. C., John Fraedrich, and Linda Ferrell, "Business Ethics: Ethical Decision Making and Cases." Boston, Mass.: Houghton Mifflin, 2000.

[22] Fombrun, C. J., N. A. Gardberg, and M. L. Barnett, "Opportunity Platforms and Safety Nets: Corporate Citizenship and Reputational Risk, " Businessand Society Review, 105, pp.85-106, 2000

[23] Forbrun, C. \& Shanley, M., "What's in a name? Reputation building and corporate Strategy". Academy of Management Journal, 33(2): 233-258, 1990.

[24] Frederick, W. C. "From CSR1 to CSR2: The Maturing of Business-and-Society Thought". Business and Society, 33, 1994.

[25] Freeman, R. Edward. "Strategic management: A stakeholder approach", Boston: Pitman. 1984.

[26] Friedman, M. "The Social Responsibility of Business is to Increase its Profits."The New York Times Magazine, 13, 32-33. 1970, 1984

[27] Garner, J., L.J. Nam and R.E. Ottoo "Eterminants of corporate growth opportunities of emerging firms?" Journal of Economics and Business, 54(1), 73-93, 2002.

[28] Gillan, S. L., "Option-Based Compensation: Panacea or Pandora's Box?" Journal of Applied Corporate Finance, Summer: pp.115-128, 2001.

[29] Hitt, M. A., Tihanyi, L., Miller, T., \& Connelly, B. "International diversification: Antecedents, outcomes, and moderators". Journal of Management, 32(6), pp.831-867, 2006.

[30] Hsu, F. J., \& Chen, Y. C. "Is a firm's financial risk associated with corporate social responsibility?" Management Decision, 53(9): 2175-2199.2015

[31] Huang, C. L. \& F. H. Kung, "Drivers of Environmental Disclosure and Stakeholder Expectation: Evidence from Taiwan", Journal of Business Ethics, Vol. 96, 435-451, 2010.

[32] Li-Hua Cheng., "A Study on Social Responsibility and Corporate Philanthropy of the Benchmarking Enterprise in Taiwan: Taking F Group as an Example" Journal Of China Institute of Technology. Vol.27, pp. 158-173, 2002.

[33] Lee, D. D., \& Faff, R. W. Corporate sustainability performance and idiosyncratic risk: A global perspective. Financial Review, 44(2): 213-237. 2009. 
[34] Jarrell, G., K. Lehn, and W. Marr, "Office of the Chief Economist, Securities and Exchange Commission". Institutional Ownership, Tender Offers, And Long-Term Investments, Jen-Ten Liu. Hsiou-Wei W. Lin. Chen-Lung Chin. "Path Analysis of Value Chain of Innovation: An Empirical Study of R\&D Investment", Management Review, 24, 29-56, 2005.

[35] Kim, Gimun, Bongsik Shin, Kyung Kyu Kim, and Ho Geun Lee. "IT Capabilities, Process-oriented Dynamic Capabilities, and Firm Financial Performance", Journal of the Association for Information Systems, 12(7), July, 487-517, 2011.

[36] Kun-Hong Lin, "A Corporate Social Responsibility Study in Kaohsiung City's Financial Institutions", Masters Dissertation, National Sun Yat-Sen University, 2004,Public Affairs Management Research Institute, Kaohsiung

[37] Kotabe, M., Srinivasan, S. S., \& Aulakh, P. S. "Multinationality and firm performance: The moderating role of R\&D and marketing capabilities". Journal of International Business Studies, 33(1), pp.79-97,2002.

[38] Kothari, S.P., and J. L. Zimmerman "Price and return models, " Journal of Accounting \& Economics, 20(2), pp.155-192, 1995.

[39] Li, S., B. Ragu-Nathan., T. S. Ragu-Nathan, and S. Subb Rao, "The Impact of Supply Chain Management Practices on Competitive Advantage and Organizational Performance", Omega 34, 107-24, 2006.

[40] Long-Gi Chen. Ni Weng. "A Study of the Relation Between Employees Stock Ownership Plan and Company Performance", Management Review, pp81-102, 1992.

[41] Maignan, I. \& O. C. Ferrell, "Corporate Citizenship as a Marketing Instrument", European Journal of Marketing, Vol. 35(3-4), 457-484, 2001.

[42] Matten, A. \& Crane, D. "Corporate citizenship: Toward an extended the Oretical conceptualization". Academy of Management Review, 30 (1):166-179, 2005.

[43] Morbey, G.K. and R.M. Reithner "How R\&D Affects Sales Growth, Productivity and Profitability?" Research Technology Management, 33(3), pp. 11-14, 1990.

[44] Moussavi, F. and D. Evans "An Attributional Approach to Measuring Corporate Social Performance," Working Paper, Academy of Management Meetings in San Diego.1986.

[45] Official Website for CSR Research Center, Division of Economics, Chinese Academy of Social Sciences, http://www.cass-csr.org/

[46] Orlitzky, M., F. L. Schmidt, \& S. L. Rynes "Corporate Social and Financial Performance: A Meta-analysis", Organization Studies, Vol. 24, pp.403-441, 2003.

[47] Peloza, J. "Using Corporate Social Responsibility as Insurance for Financial Performance," California Management Review, 48, pp.52-72, 2006.

[48] Porter, M. E. and C. van der Linde "Green and Competitive; Ending the Stalemate," Harvard Business Review, September-October, 120-135, 1995.

[49] Sethi, S. P. (1975), "Dimensions of corporate social performance: An analytical framework." California
Management Review, Vol.17 (3):58-64, 1975.

[50] Shrivastava, P. "The Role of Corporations in Achieving Ecological Sustainability", Academy of Management Review, Vol. 20(40), pp.936-960, 1995.

[51] Shi-Boh Chen. "Banking Customer Relationship Management System and Business strategy relevance" Journal of Taiwan Economic and Financial Monthly" Vol.43-9, 35-36, 2007.

[52] Skinner, D. J., "Are Disclosures About Bank Derivatives and Employee Stock Options Value-Relevant?" Journal of Accounting and Economics, 22: 393-405, 1996.

[53] Spicer, B. H. "Investors, Corporate Social Performance and Information Disclosure: An Empirical Study, " Accounting Review, 53, pp.94-111, 1978.

[54] Sullivan, D. "MEASURING THE DEGREE OF INTERNATIONALIZATION OF A FIRM". Journal of International Business Studies, 25(2), pp.325-342,1994.

[55] Turban, D. B. and D. W. Greening "Corporate Social Performance and Organizational Attractiveness to Prospective Employees," Academy of Management Journal, 40, pp.658-672, 1997.

[56] Tsai, S. C. "Valuation of R\&D and advertising expenditures," Journal of Contemporary Accounting, Vol.2 (1), 41-76, 2001.

[57] Tsoutsoura, M. "Corporate Social Responsibility and Financial Performance," Working Paper, University of California, 2004.

[58] Verwijmeren, P., \& Derwall, J. "Employee well-being, firm leverage, and bankruptcy risk". Journal of Banking \& Finance, 34(5): 956-964. 2010.

[59] Walley, N. and B. Whitehead, "It’s Not Easy Being Green." Harvard Business Review, 72, 2-7, 1994.

[60] Wartick, S. L. \& Cochran, P. L. "The evolution of the corporate social performance model". Academy of Management Review, Vol.10 (4): pp.758-769, 1985.

[61] Werther, W. and D. Chandler "Strategic Corporate Social Responsibility as Global Brand Insurance," Business Horizons, 48, pp.317-324, 2005.

[62] Williamson, O. E. "Markets and Hierarchies, Free Press, New York. Wood, D. J. Corporate social performance revisited “. Academy of Management Review, 16:691-718, 1991.

[63] Xiao, S. S., Jeong, I., Moon, J. J., Chung, C. C., \& Chung, J. "Internationalization and Performance of Firms in China: Moderating Effects of Governance Structure and the Degree of Centralized Control", Journal of International Management, 19(2), pp.118-137, 2013.

[64] Zhu, Q. \& Sarkis, J. "Relationships between operational practices and performance among early adopters of green supply chain management practices in Chinese manufacturing enterprises". Journal of Operations Management, 22, pp.265-289,2004. 